\title{
Storage Potentialities of Some Exotic Potato Varieties at Farmers' Condition in Bangladesh
}

\author{
Abul Kalam Azad ${ }^{1}$, Humayun Kabir'1, Touria El-Jaoual Eaton², Edward Binod Soren ${ }^{1}$ \\ ${ }^{1}$ Department of Crop Science \& Technology, Rajshahi University, Rajshahi, Bangladesh \\ ${ }^{2}$ Department of Horticulture, Lincoln University of Missouri, Jefferson City, USA \\ Email:^azad.adrinwa@gmail.com
}

How to cite this paper: Azad, A.K., Kabir, H., Eaton, T.E.-J. and Soren, E.B. (2017) Storage Potentialities of Some Exotic Potato Varieties at Farmers' Condition in Bangladesh. Agricultural Sciences, 8, 183-193. https://doi.org/10.4236/as.2017.82013

Received: January 3, 2017

Accepted: February 19, 2017

Published: February 22, 2017

Copyright (c) 2017 by authors and Scientific Research Publishing Inc. This work is licensed under the Creative Commons Attribution International License (CC BY 4.0).

http://creativecommons.org/licenses/by/4.0/

\section{c) (i) Open Access}

\begin{abstract}
Potatoes have to be stored after harvest for a shorter or longer period in order to maintain even supply to the market throughout the year for direct human consumption as well as for the processing industry. The present study focused on the storage potentialities of six exotic varieties of potato viz., Diamant, Cardinal, Granola, Felsina, Provento and Asterix at farmers' condition. The experiment was conducted during winter (December to March) for cultivation, and spring and summer (March to August) for storage at Domar Foundation Seed Potato Production Farm, BADC, Nilphamari, Bangladesh. Results revealed that there were significant variations in storage behavior among the varieties of potato tubers. Asterix showed minimum weight loss (7.10\%) which was statistically identical with Cardinal $(7.85 \%)$ while it was maximum in Felsina (18.83\%) followed by Provento (13.41\%) during four months storage conditions practicing by farmers (farmers' conditions). In respect of rotting, significantly highest degree was found in Felsina (18.72\%) followed by Provento (15.01\%) and the lowest was in Asterix (2.02\%) identically similar with Granola (2.22\%). The highest percentage of water loss was found in Provento $(27.01 \%)$ and the lowest was recorded in Asterix (17.03\%). Dormancy period and sprouts per tuber were found highest in Asterix (70 days and 9.67) while the lowest dormancy was in Diamant (56 days) and the lowest sprouting was in Granola (2.50). Asterix was found to produce significantly highest amount of dry matter content (20.50\%) along with higher amount of edible stored tubers (80.21\%) compared to those of other varieties at the end of four months storage. Under the same condition, Diamant was the second highest producer of dry matter (20\%) which was statistically similar with Asterix, and had good storage ability that retained $69.07 \%$ edible tubers, whereas Felsina contained the lowest amount of dry matter (16\%) and showed poor storage ability retaining $55.85 \%$ edible tubers. Based on the results, Asterix possessed better keeping quality with long dormancy, minimum weight loss, higher tuber dry matter with edible tuber, excellent storage ability, low storage losses
\end{abstract}


and rotting. However, the variety Asterix may be recommended for commercial storage under ordinary storage condition or farmers' practice. Diamant ranked in second position considering the above circumstances, although showed better performances compared to the rest of the studied varieties.

\section{Keywords}

Potato, Sprouting Behavior, Dormancy, Weight Loss, Tuber Dry Matter Content

\section{Introduction}

Potato (Solanum tuberosum L.) belongs to the family solanaceae is a tuber crop which is an underground modified stem. Among the major staple foods of the world, the status of potato is third. It is a key part of global sustainable food system producing more food energy on less land than rice, wheat and maize [1]. It is rich in calories, carbohydrates and proteins as well as substantial amount of vitamins. Potato is one of the greatest food crops of the world that alone combines the desirable characteristics of high yield, low cost and a nutritious and palatable food [2]. It produces the highest dry matter per unit area compared to that of other crops. Recently potato has become major food crop in Bangladesh because of its multiple uses as vegetable and delicious processed items. There is a wide gap between average national yield of potato in Bangladesh compared to other potato growing countries of the world like Netherlands, UK, France, USA and Germany. Potato yield in UK is about $48 \mathrm{MT} / \mathrm{ha}$, which is more than two and a half times higher than that of Bangladesh [3]. It is the $3^{\text {rd }}$ most important crop of Bangladesh followed by rice and wheat [4]. More than half of global potato production is in developing countries like Bangladesh rendering an important source of food and income of millions of farmers [5].

Storage is necessary for considerable period of time after harvest for a regular supply of potatoes to the consumers during offseason. It can be done in two ways, 1) in cold stores under controlled environment and 2) in the houses under ordinary room condition. A small part of the rest is consumed shortly after harvesting and the bulk is stored under ordinary storage conditions. This causes certain percentage of damage due to sprouting, respiration, water loss and rotting. Therefore, it is important to preserve potatoes to maintain the potato supply throughout the year.

Freshly harvested potatoes like other tuber crops contain more than $70 \%$ moisture and are perishable in nature. These crops cannot be saved from spoilage unless properly preserved. However, many of the small and marginal farmers of Bangladesh cannot afford to store potato as they need cash to meet their production expenses or don't have access to cold store in their surroundings. Under such circumstances, farmers resort to distress sale, and traditional storage system could be an answer to this but for this knowledge of storage behavior of different 
varieties which can withstand ambient temperatures at least for 60 - 75 days is very important enabling the farmers to sale their produce periodically. Previous studies on keeping quality [6]-[11] conducted under ambient conditions or under non refrigerated storage [12] [13] were limited to a few hybrid varieties. Pande et al. [14] conducted an extensive study on sprouting behavior and weight loss of potato varieties under controlled conditions, but, consolidated information on storage behavior of potato varieties under ambient conditions is lacking.

The farmers of Bangladesh usually keep their potato spread on the elevated platforms created in their dwelling houses. Some other crude methods are also used. These methods are only partially effective for storing potatoes for one or two months depending on the varieties. As potato is a semi-perishable crop it can be stored for over 6 months at $3^{\circ} \mathrm{C}-4^{\circ} \mathrm{C}$ in cold store. Due to improper handling and storage a huge amount of potato perishes every year causing spoilage and sprouting. For large scale commercial preservation of potatoes cold storages are used in Bangladesh. But with the present limited facilities in Bangladesh only $25 \%$ of the total production can be stored. The total number of cold storages in the country is much lower than that actually needed. There are altogether 283 cold storages of which some are out of operation due to various reasons. Average capacities of these cold storages are 2500 metric tons [15]. To preserve the produced potatoes in Bangladesh, the number of cold storages should be increased by about 5 times the present number. Seed potatoes have to be stored after harvest till the next planting time. In our experiment potatoes of six modern varieties were used and analyzed their performances in weight loss, percentages of water loss, rotting, dormancy period, sprouts per tuber, dry matter content and edible tuber for three months storage period. In considering the above facts, the present study with six exotic varieties of potato was conducted at BADC farm, Nilphamari, Bangladesh during the period from December to August with a view to select suitable variety having good storage ability under ordinary storage conditions.

\section{Materials and Methods}

\subsection{Background Information of the Studied Site}

This study was conducted at the Domar Foundation Seed Potato Production Farm, Bangladesh Agricultural Development Corporation (BADC), Nilphamari located in North of Bangladesh (24 $22^{\prime}$ North latitude and $88^{\circ} 35^{\prime}$ East longitude). Its altitude is $18.6 \mathrm{~m}$.

The winter season is suitable for growing potato crop. During which period, the mean maximum temperature was $29^{\circ} \mathrm{C}$ and the minimum temperature was $9^{\circ} \mathrm{C}$. The mean relative humidity, wind speed, total precipitation and total evaporation amounted to $57 \%, 1.26 \mathrm{~m} / \mathrm{s}, 31 \mathrm{~mm}$ and $51 \mathrm{~mm}$ respectively.

\subsection{Materials}

Seed tubers of six Dutch varieties of potato namely Diamant, Cardinal, Granola, Felsina, Provento and Asterix were cultivated from December 8, 2008 to March 
5, 2009 for field trial and from March 20, 2009 to August 20, 2009 for storage trial. Recommended crop management practices were followed to grow the crop. Haulms were cut 90 days after planting. The crop was harvested 10 - 15 days after haulm cutting to allow the tubers to attain skin firmness. The tubers collected from each plot were weighed for a total weight $(\mathrm{Wt})$, then sorted and seed tubers were placed in heated trays in BADC.

\subsection{Layout and Design for Storage of Potato}

The collected seed tubers (sample) were cured at room temperature for 15 days. Then they were placed in plastic crates. For sorting and grading $100 \mathrm{~kg}$ of each variety were taken. Non seed tubers were sorted out on the basis of mechanical injury, disease infestation, insect damage and physiology of the tubers. After completion of sorting, $15 \mathrm{~kg}$ of seed tubers $(28-55 \mathrm{~mm}$ ) of each variety were taken in each crate and was placed them in RCBD fashion with three replications. However, 18 crates were used for six varieties. The number of potato tubers was counted in each crate and the crates were placed on the floor of a well ventilated room of Domar Foundation Seed Potato Production Farm, BADC, Nilphamari for a period of 4 months.

When sorting was completed and data were collected, tubers of the same variety were mixed, divided randomly in 3 parts and put in plastic crates for storage. Total crates were 18 (6 varieties $\times 3$ replicates). The crates were stacked randomly in the storage room at the Domar Foundation Seed Potato Production Farm, BADC, Nilphamari. The room was well ventilated, and the ventilation was situated on the upper most portion of the storage side wall. Ventilations were used for passing air and light as when necessary. The room was kept dark at temperature $45^{\circ} \mathrm{F}$, and potato tubers were then stored for 4 months starting from March 20, 2009 to August 20, 2009.

\subsection{Storage Behavior}

At the beginning of the storage period, the tubers of each crate were weighed for an initial weight (Wi). During the four months storage period, the tubers were inspected every 20 days. Data collection on rotting was done at 20 days interval and the rotted tubers were separated. Healthy tubers and rotted tubers of each crate were weighed, and then rotted tubers were discarded. At each date of inspection, the percentage of total rotting was calculated as the ratio of weight of rotten tubers at the time of inspection to the initial weight (Wi). The percentage of weight loss was calculated as the ratio of the weight of total tubers (healthy + rotted) at the time of inspection, to the initial weight of the tubers (Wi) (Table 1 \& Table 2).

\subsection{Final Weight of Edible Tubers (\%)}

Percent final weight of edible tubers was calculated as the ratio of weight retained by edible stored tubers at the end of the experiment to the initial weight of sample and then expressed in percentage (Table 2). 
Table 1. Effect of different storage duration on weight loss percentages of modern potato varieties under ordinary storage conditions (farmers' condition).

\begin{tabular}{ccccccc}
\hline \multirow{2}{*}{$\begin{array}{c}\text { Name of } \\
\text { varieties }\end{array}$} & \multicolumn{5}{c}{ Weight loss percentage at different storage duration } \\
\cline { 2 - 7 } & 20 DAS & 40 DAS & 60 DAS & 80 DAS & 100 DAS & 120 DAS \\
\hline Diamant & $2.78(1.658) \mathrm{a}$ & $2.40(1.549) \mathrm{ab}$ & $3.34(1.825) \mathrm{b}$ & $4.89(2.203) \mathrm{bc}$ & $7.56(2.74) \mathrm{b}$ & $9.96(3.145) \mathrm{bc}$ \\
Cardinal & $1.73(1.524) \mathrm{ab}$ & $2.96(1.718) \mathrm{a}$ & $5.12(2.261) \mathrm{a}$ & $6.00(2.449) \mathrm{ab}$ & $6.40(2.530) \mathrm{bc}$ & $7.85(2.793) \mathrm{c}$ \\
Granola & $2.00(1.415) \mathrm{ab}$ & $1.67(1.262) \mathrm{b}$ & $3.12(1.763) \mathrm{bc}$ & $3.56(1.996) \mathrm{c}$ & $6.00(2.447) \mathrm{bc}$ & $9.56(3.089) \mathrm{bc}$ \\
Felsina & $1.65(1.282) \mathrm{bc}$ & $1.33(1.246) \mathrm{b}$ & $2.34(1.526) \mathrm{cd}$ & $7.78(2.774) \mathrm{a}$ & $12.23(3.451) \mathrm{a}$ & $18.83(4.315) \mathrm{a}$ \\
Provento & $2.51(1.581) \mathrm{ab}$ & $2.78(1.654) \mathrm{a}$ & $4.34(2.081) \mathrm{a}$ & $7.67(2.769) \mathrm{a}$ & $11.34(3.366) \mathrm{a}$ & $13.41(3.660) \mathrm{b}$ \\
Asterix & $1.13(1.062) \mathrm{c}$ & $1.45(1.190) \mathrm{b}$ & $2.22(1.479) \mathrm{d}$ & $2.45(1.520) \mathrm{d}$ & $4.78(2.185) \mathrm{c}$ & $7.10(2.663) \mathrm{c}$ \\
CV (\%) & 13.60 & 12.97 & 7.60 & 9.77 & 10.49 & 9.62 \\
\hline
\end{tabular}

All results were analyzed after square root transformation. In a column figures bearing same letter(s) do not differ significantly $(\mathrm{p}<0.05)$.

Table 2. Storage behaviour of six exotic potato varieties during 4 months storage under ordinary storage condition (farmers' condition).

\begin{tabular}{|c|c|c|c|c|c|c|}
\hline \multirow{2}{*}{$\begin{array}{l}\text { Name of } \\
\text { varieties }\end{array}$} & \multicolumn{2}{|c|}{ Total weight loss in 4 months of storage } & \multirow{2}{*}{$\begin{array}{l}\text { Final weight of edible } \\
\text { tubers after } 4 \text { months (\%) }\end{array}$} & \multirow{2}{*}{ Number of sprouts per tuber } & \multirow{2}{*}{$\begin{array}{l}\text { Dry matter } \\
\text { content }(\%)\end{array}$} & \multirow{2}{*}{$\begin{array}{c}\text { Period of } \\
\text { Dormancy (days) }\end{array}$} \\
\hline & Total rotting (\%) & Total water loss (\%) & & & & \\
\hline Diamant & $10.18(3.174) b$ & $20.75(4.551) b c$ & $69.07 \mathrm{~b}$ & $5.50 \mathrm{c}$ & $20.00(4.47) \mathrm{a}$ & 56 \\
\hline Cardinal & $3.81(1.974) \mathrm{c}$ & $26.23(5.121) \mathrm{a}$ & $69.96 \mathrm{~b}$ & $7.71 \mathrm{~b}$ & $19.00(4.36) \mathrm{ab}$ & 61 \\
\hline Granola & $2.22(1.472) \mathrm{c}$ & $23.01(4.797) \mathrm{ab}$ & $74.76 \mathrm{ab}$ & $2.50 \mathrm{~d}$ & $15.40(4.12) \mathrm{bc}$ & 67 \\
\hline Felsina & $18.72(4.274) \mathrm{a}$ & $25.44(5.032) \mathrm{a}$ & $55.85 \mathrm{c}$ & $6.33 \mathrm{bc}$ & $16.00(3.99) \mathrm{c}$ & 65 \\
\hline Provento & $15.01(3.866) \mathrm{ab}$ & $27.01(5.196) \mathrm{a}$ & $57.98 \mathrm{c}$ & $3.50 \mathrm{~d}$ & $16.40(4.05) \mathrm{c}$ & 60 \\
\hline Asterix & $2.02(1.378) \mathrm{c}$ & $17.03(4.12) \mathrm{c}$ & $80.21 \mathrm{a}$ & $9.67 \mathrm{a}$ & $20.50(4.53) \mathrm{a}$ & 70 \\
\hline CV (\%) & 12.75 & 5.44 & 7.29 & 9.20 & 4.39 & NA \\
\hline
\end{tabular}

Total rotting (\%), total water loss (\%) and dry matter content (\%) were analyzed after square root transformation. In a column figures bearing the same letter(s) do not differ significantly $(\mathrm{p}<0.05)$. NA = Not Analyzed.

\subsection{Number of Sprouts per Tuber}

Ten tubers of each variety were randomly taken and sprouts were counted. Then the values were averaged per tuber (Table 2).

\subsection{Dry Matter Content (\%)}

For determination of dry matter content, $100 \mathrm{~g}$ of potato tubers as sample were taken randomly from each variety. The samples were sliced and dried well by sun for 2 days. After sun drying, the samples were dried by oven for 24 hours at $70^{\circ} \mathrm{C}$. Dry matter content was estimated as the ratio of dry weight to the initial weight of sample and then it was expressed in percentage.

\subsection{Statistical Analysis}

Data obtained for storage behavior were statistically analyzed to find out the significance of the differences among the treatments using Duncan's multiple range test [16]. The mean values of all the parameters for 6 varieties were calculated and the analysis of variance (ANOVA) was performed by "F" (variance ratio) 
test. The significant of differences among the treatment means were evaluated by least significant differences (LSD) ( $\mathrm{p}<0.05$ ) [17] using MSTAT-C program.

\section{Results and Discussion}

\subsection{Weight Loss of Tubers (\%)}

Weight loss after harvest reduces the quality of vegetable that need to be kept in fresh condition. Reduction in weight of tubers due to evaporative losses from the tuber surface is considered as physiological weight loss. Loss in weight of tubers in storage usually occurs due to water loss, rotting and sprouting. Respiration and evaporation result in water loss and ultimately reduce the market quality of stored tubers. Decrease in weight due to evaporation of water may be ten times greater than that of respiration loss [18].

Significant differences were observed in the storage behavior of six modern potato varieties. Continuous weight loss throughout the entire period of four months storage was recorded at every 20 days interval.

At 20 days after storage, maximum weight loss was recorded in Diamant (2.78\%) which was statistically similar with Provento (2.51\%), Granola $(2.0 \%)$ and Cardinal (1.73\%), while minimum weight loss was found in Asterix (1.13\%) similar with Felsina (1.65\%) (Table 1).

At 40 days of storage, Cardinal showed maximum weight loss (2.96\%) which was statistically identical with Provento $(2.78 \%)$ and similar with the variety Diamant (2.40\%). Alternatively, Felsina (1.33\%) showed minimum weight loss and was statistically identical with Asterix (1.45\%) and Granola (1.67\%) (Table 1).

At 60 days of storage, maximum weight loss was found in Cardinal (5.12\%) which was statistically identical with Provento (4.34\%) while minimum weight loss was found in Asterix (2.22\%) similar with Felsina (2.34\%) (Table 1).

At 80 days of storage, Felsina (7.78\%) showed maximum weight loss which was identical with Provento (7.67\%) and similar with Cardinal (6.0\%). Asterix (2.45\%) showed minimum weight loss followed by Granola (3.56\%) (Table 1).

At 100 days of storage, maximum weight loss was observed in Felsina (12.23\%) that was statistically identical with Provento (11.34\%) followed by Diamant (7.56\%). Minimum weight loss was found in Asterix (4.78\%) which was statistically similar with Granola (6.00\%) and Cardinal (6.40\%) (Table 1).

At 120 days of storage, Felsina showed maximum weight loss (18.83\%) followed by Provento (13.41\%). Asterix showed the minimum weight loss $(7.10 \%)$ which was statistically identical with Cardinal (7.85\%) and similar with Granola (9.56\%) and Diamant (9.96\%) (Table 1).

It is generally believed that varieties with longer dormancy period may perform better under non-refrigerated storage conditions. It has been reported that sprouted potatoes loose much more weight than un-sprouted potatoes [19]. Ezekiel et al. [20] reported that weight loss in potato varieties during storage is related with the periderm thickness, number of cell layers in the periderm and also with the number of lenticels on the tuber surface. Among the varieties tested, percent weight loss was lowest in the variety Asterix followed by Cardinal, while 
highest in Felsina as performed the worst (Table 1) over a period of 120 days as the weight loss.

\subsection{Sprouting Behavior and Dormancy Period}

When potato is stored for table purpose, the early sprouting is undesirable, as it reduces the quality of potato tubers. Significant variations among the varieties were recorded with respect to sprouting behavior per tuber and dormancy period at the end of four months storage period (Table 2).

The results on sprouting behavior (Table 2) revealed that all varieties did not sprout till 56 days of storage, and started sprouting within 8 to 10 weeks. The maximum number of sprouts per tuber was observed in Asterix (9.67) followed by Cardinal (7.17) and Felsina (6.33). Minimum number of sprouts per tuber was found in Granola (2.50) which was statistically identical with Provento (3.50).

The highest period of dormancy was observed in Asterix (70 days) followed by Granola (67 days) and Felsina (65 days) while lowest period was recorded in Diamant (56 days). Gupto et al. [21] reported closer results to the present findings using 44 potato varieties where the starting period of sprouting was 45 days. Dormancy is considered to be the varietal character that might gets influenced by the soil and environmental conditions during crop growth and storage environment [22].

Anonymous [23] while working with 31 potato varieties reported that $\mathrm{Pa}$ trones sprouted within 9 to 12 weeks while Cardinal and others 7 to 9 weeks. The results of the present finding are also similar to this report. Alternatively, current result showed shorter dormancy period similar to that of Hossain and Abbas [24]. Burton [25] studied the dormancy period among several potato varieties of Great Britain and found that dormancy period of potato tubers varied according to variety as well as storage temperature.

\subsection{Tuber Rotting}

Potato tubers whether stored under ordinary or refrigerated storage condition some extent of rotting always occurs. The lower percentage of rotting is expected for storage of the potato tuber. Rottage makes the tuber unfit for consumption and also induces the infection in the adjacent tubers kept for storage. Table 2 showed that the extent of rotting varied greatly among the potato varieties when stored under ordinary storage condition or farmers' condition for four months (120 days). The mean percent rottage by weight, in three of the varieties remained from $2.02 \%$ to $3.81 \%$ (Asterix, Granola and Cardinal), and the other three ranged from $10.18 \%$ to $18.72 \%$ (Felsina, Provento and Diamant). However, Felsina (18.72\%) exhibited significantly higher rottage as compared to other varieties followed by Provento (15.01) and Diamant (10.18\%). Alternatively, the significant lowest percentage of rotting was observed in Asterix (2.02\%) which was statistically identical with Granola (2.22\%) and Cardinal (3.81\%). The variable response of different genotypes, prevailing temperature and humidity might 
have attributed to variable rottage percentage. Raghav and Singh [26] in an experiment involving 12 potato varieties under room temperature, found various rottage percentages in their varieties.

\subsection{Total Water Loss Percentage}

Total weight loss in potato varieties determines the longevity of their storage and also their keeping quality. The lower percentage of water loss is expected for potato storage. Total weight loss including evaporative and respiratory weight loss of tubers \& sprouts and weight loss due to rottage at 120 days of storage showed large variation between varieties under ordinary storage condition or farmers' condition (Table 2). Mean total weight loss was recorded significantly highest in the variety Provento $(27.01 \%)$ which was statistically similar with Cardinal (26.23\%) and Felsina (25.44\%) followed by Granola (23.01\%) (Table 2). Asterix exhibited significantly lowest mean total weight loss (17.03\%) followed by $\mathrm{Di}$ amant (20.75\%). Total weight loss, like rottage and physiological weight loss was also significantly high due to higher temperature and relative humidity. A number of studies [7] [8] [27] related to different potato varieties are in accordance with the present findings. The potato varieties with minimum total weight loss retain the tuber firmness and fetches good market prices for longer period of time. Such varieties could also be promoted for long distance transportation and export purpose as well.

\subsection{Dry Matter (\%) Content of Tuber}

Textures of cooked potato as well as starch content of tubers are greatly influenced by its dry matter content. Tuber dry matter is important parameter for considering the suitability of potatoes for different purposes. The higher the dry matter content, the lesser the disintegration of cooked potato and the higher the content of starch. After considering all these factors Beukems and Zaag [28] commented that the dry matter content of potato tuber is an important character that determines the quality of the tuber. Significant variations were observed among the tested varieties in respect of dry matter (\%) content of tubers. Table 2 showed that the percent of dry matter content ranged from $15.40 \%$ to $20.50 \%$ at the end of 120 days of storage in our tested varieties in Bangladesh. These results are closely accordance with those of Gupto et al. [21] who found the ranges of dry matter content from $16.1 \%$ to $24.2 \%$ in their experiments with potatoes. These results are similar to the findings of Beukema and Zaag [28] who reported that the dry matter content of potato tuber to be $15.40 \%$ to $22.40 \%$. These are also nearer to that of Anonymous [29], who found that dry matter percentage of the maximum potato varieties ranged from $15 \%$ to $24 \%$. The highest dry matter content (\%) was observed in the variety Asterix (20.50\%) which was statistically identical with Diamant (20.0\%) and Cardinal (19.0\%). Alternatively, the lowest dry matter was obtained in Granola (15.40) that was statistically similar with Felsina (16.0\%) and Provento (16.40\%). 


\subsection{Final Weight of Edible Tubers (\%)}

The final weight (\%) of edible tubers refers the amount of tubers that retained after water loss and losses due to sprouting and rotting. The higher the final weight retained, the higher would be the storage ability of potato tubers.

There were significant variations among the varieties in retaining final weight of edible tubers at the end of storage period of 120 days (Table 2). Asterix retained significantly highest weight $(80.21 \%)$ followed by Granola $(74.76 \%)$ which was statistically identical with Cardinal (69.96\%) and Diamant (69.07\%), whereas Cardinal and Diamant were statistically similar to each other. Felsina (55.85\%) retained the lowest weight of edible tuber and was statistically similar with Provento (57.98\%).

\section{Conclusion}

Comparative studies were made with six exotic varieties of potato to evaluate their storage behavior under ordinary storage condition. Among the characters studied on storage behaviors, the varieties showed differences in extent of total rotting (\%), total water loss (\%), weight loss (\%), final weight of edible tubers, number of sprout per tuber, dry matter content (\%) and period of dormancy. Asterix showed minimum weight loss (7.10\%) and water loss (17.03\%), lowest rotting rate $(2.02 \%)$, highest dormancy period (70 days) during four months storage. The final weight of edible tubers at the end of storage was found to vary greatly ranging from $55.85 \%$ to $80.21 \%$. Asterix was the best among the varieties claiming highest dry matter $(20.50 \%)$ in retaining maximum amount of edible tubers (80.21\%) after long storage period of four months. All the varieties started sprouting within 8 to 10 weeks. Considering the results, Asterix possessed excellent keeping quality with medium to long tuber dormancy, low storage losses and rotting and higher tuber dry matter. However, the variety Asterix may be recommended for commercial storage under ordinary storage condition. Diamant ranked second in position considering the above circumstances though it showed better performances in many parameters compared to the rest of the varieties.

\section{References}

[1] Munira, S., Hossain, M.M., Zakaria, M., Ahmed, J.U. and Islam, M.M. (2015) Evaluation of Potato Varieties against Salinity Stress in Bangladesh. International Journal of Plant \& Soil Science, 6, 73-81. https://doi.org/10.9734/IJPSS/2015/15879

[2] Wolf, T.K. and Kipps, M.S. (1959) Production of Field Crops. 5th Edition, McGrawHill Book Co. Inc., New York, 321 p.

[3] Saha, K.M. and Hossain, M.S.M. (2011) An Analysis of Present Production and Marketing Situation in Bangladesh. Hortex Foundation Newsl, 11, 1-8.

[4] BBS (2009) Statistical Yearbook of Bangladesh. Bangladesh Bureau of Statistics, Statistics Division, Ministry of Planning, Government of the People's Republic of Bangladesh, 135-146.

[5] Sabur, S.A. and Gangwar, A.C. (2005) Demand-Supply Projections of Potato in Bangladesh. Bangladesh Journal of Agriculture, 10, 59-66. 
[6] Kang, G.S. and Gopal, J. (1993) Differences among Potato Genotypes in Storability at High Temperature after Periods of Storage. Journal of Indian Potato Association, 20, 105-110.

[7] Singh, S.V., Pandey, S.K. and Khurana, S.M.P. (2001) Storage Behaviour of Some Advanced Potato Hybrids in Plains of Western UP at Ambient Temperatures. Journal of Indian Potato Association, 28, 135-136.

[8] Patel, R.N., Kanbi, V.H., Patel, C.K., Patel, N.H. and Chaudhari, S.M. (2002) Room Temperature Storage of Some Advanced Potato Hybrids and Varieties in the Plains of Gujarat. Journal of Indian Potato Association, 29, 159-161.

[9] Pande, P.C. and Luthra, S.K. (2003) Performance and Storability of Advanced Potato Hybrids in West Central Plains. Journal of Indian Potato Association, 30, 21 22.

[10] Das, M., Ezekiel, R., Pandey, S.K. and Singh, A.N. (2004) Storage Behaviour of Potato Varieties and Advanced Cultures at Room Temperature in Bihar. Potato Journal, 31, 71-75.

[11] Kumar, R., Pandey, S.K. and Khurana, S.M.P. (2005) Keeping Quality of Potato Processing Varieties during Room Temperature Storage. Potato Journal, 32, 55-59.

[12] Mehta, A. and Kaul, H.N. (1997) Physiological Weight Loss in Potatoes under Non-Refrigerated Storage: Contribution of Respiration and Transpiration. Journal of Indian Potato Association, 24, 106-113.

[13] Mehta, A., Singh, S.V., Pandey, S.K. and Ezekiel, R. (2006) Storage Behaviour of Newly Released Potato Cultivars under Non-Refrigerated Storage. Potato Journal, 33, 158-161.

[14] Pande, P.C., Singh, S.V., Pandey, S.K. and Singh, B. (2007) Dormancy Sprouting Behaviour and Weight Loss in Indian Potato (Solanum tuberosum) Varieties. International Journal of Agricultural Science, 77, 715-720.

[15] Islam, M.M., Kabir, H.M., Sattar, M.A. and Kabir, M.S. (2008) Management Practices in Some Selected Cold Storage in Bangladesh. Journal of Innovative Development strategy, 2, 48-54.

[16] Duncan, D.B. (1955) Multiple Ranges and Multiple F-Test. Biometrics, 11, 1-42. https://doi.org/10.2307/3001478

[17] Gomez, K.A. and Gomez, A.A. (1984) Statistical Procedure for Agricultural Research. 2nd Edition, John Wiley and Sons, New York, 680 p.

[18] Alauddin, M. (1978) Preservation of Potato Procedure. 1st Workshop of Potato Research Workers, Dhaka, 28-30 March 1978, 91-94.

[19] Van, E.A. and Hartmans, K.J. (1987) Dormancy, Sprouting and Sprout Inhibition. In: Rastovski, A., van Es, A., et al., Eds., Storage of Potatoes: Post-Harvest Behavior, Store Design, Storage Practice, Handling, Pudoc, Wageningen, 114-132.

[20] Ezekiel, R., Singh, B., Sharma, M.L., Garg, I.D. and Khurana, S.M.P. (2004) Relationship between Weight Loss and Periderm Thickness in Potatoes Stored at Different Temperatures. Potato Journal, 31,135-140.

[21] Gupto, V.K., Luthra, S.K. and Singh, B.P. (2015) Storage Behaviour and Cooking Quality of Indian Potato Varieties. Journal of Food Science and Technology, 52, 4863-4873. https://doi.org/10.1007/s13197-014-1608-Z

[22] Ezekiel, R. and Singh, B. (2003) Seed Physiology. The Potato Production and Utilization in Sub-Tropics. Mehta Publishers, New Delhi, 301-313.

[23] Anonymous (1978) Annual Report for 1977-78. Bangladesh Agricultural Research Institute, Dacca, 25 p. 
[24] Hossain, M.A.E. and Abbas, A.M. (1977) Period of Dormancy of Different Cultivars of Potato. Proceedings of 1 st Workshop of Potato Research Workers, Dhaka, 28-30 March 1978, 69 p.

[25] Burton, W.G. (1989) Post Harvest Physiology. In: Burton, W.G., Ed., Essex. The Potato, 3rd Edition, Longman Scientific and Technical, Harlow, 423-522.

[26] Raghav, M. and Singh, N.P. (2003) Differences among Potato Cultivars for Their Storability under Room Temperature. Progress Horticulture, 35, 196-198.

[27] Kang, G.S., Kumar, R., Gopal, J., Pandey, S.K. and Khurana, S.M.P. (2007) Kufri Pushkar-A Main Crop Potato Variety with Good Keeping Quality for Indian Plains. Potato Journal, 34, 147-152.

[28] Beukemas, H.P. and Zaag, D.E.V.D. (1979) Potato Improvement', Some Facts and Forces. I.A.C. Wageningen, 103-112.

[29] Anonymous (1987) Yield and Yield Contributing Characters of Dutch Potato Germ Plasms. Annual Report, 1986-1987. Potato Research Centre, Bangladesh Agricultural Research Institute, Dhaka, 1-13.

\section{Scientific Research Publishing}

Submit or recommend next manuscript to SCIRP and we will provide best service for you:

Accepting pre-submission inquiries through Email, Facebook, LinkedIn, Twitter, etc. A wide selection of journals (inclusive of 9 subjects, more than 200 journals)

Providing 24-hour high-quality service

User-friendly online submission system

Fair and swift peer-review system

Efficient typesetting and proofreading procedure

Display of the result of downloads and visits, as well as the number of cited articles

Maximum dissemination of your research work

Submit your manuscript at: http://papersubmission.scirp.org/

Or contact as@scirp.org 